\title{
The Prairie Caddo Model and the J.B. White Site
}

Ross C. Fields

Prewitt and Associates, Inc.

Follow this and additional works at: https://scholarworks.sfasu.edu/ita

Part of the American Material Culture Commons, Archaeological Anthropology Commons, Environmental Studies Commons, Other American Studies Commons, Other Arts and Humanities Commons, Other History of Art, Architecture, and Archaeology Commons, and the United States History Commons

Tell us how this article helped you.

This Article is brought to you for free and open access by the Center for Regional Heritage Research at SFA ScholarWorks. It has been accepted for inclusion in Index of Texas Archaeology: Open Access Gray Literature from the Lone Star State by an authorized editor of SFA ScholarWorks. For more information, please contact cdsscholarworks@sfasu.edu. 


\section{The Prairie Caddo Model and the J.B. White Site \\ Creative Commons License \\ (c) $($ ) $(9)$}

This work is licensed under a Creative Commons Attribution-NonCommercial 4.0 International License 


\title{
The Prairie Caddo Model and the J.B. White Site
}

\author{
Ross C. Fields \\ Prewitt and Associates, Inc.
}

This article summarizes an hypothesis — called the Prairie Caddo model—presented in a research module published in 2006 to help explain some obvious connections in material culture between Caddo sites in east Texas and sites in central Texas. Harry J. Shafer prepared this module, entitled People of the Prairie: A Possible Connection to the Davis Site Caddo, as an outgrowth in part of excavations that Prewitt and Associates, Inc., performed at the $J$. B. White site in 2002 for the Texas Department of Transportation. Following the summary of the hypothesis is a synopsis of the results of the excavations at $J . B$. White and an assessment of the utility of that model for interpreting those results. The excavation data are not consistent with the idea that the people who lived on the Blackland Prairie at the east edge of central Texas between A.D. 1000 and 1300 were Caddo groups who served as a supporting population for the ceremonial center at the George C. Davis site, as the Prairie Caddo model would suggest. Rather, they appear to have been local hunter-gatherers who interacted regularly with the east Texas Caddo. This interaction included providing the Caddo with arrow points and knives, which apparently were highly prized by elites who lived, died, and were buried at the Davis site.

\section{Introduction}

In 2006, the Archeological Studies Program (at that time, led by Nancy A. Kenmotsu and G. Lain Ellis) of the Texas Department of Transportation's (TxDOT) Environmental Affairs Division published a monograph authored by Harry J. Shafer entitled People of the Prairie: A Possible Connection to the Davis Site Caddo (Shafer 2006; available at http://counciloftexasarcheologists.org/ wordpress/wp-content/uploads/PrairieCaddoModule. pdf).The publication, which was intended to help guide future archeological research in the eastern part of central Texas, laid out Shafer's hypothesis that Caddo groups occupied portions of central Texas, i.e., the Edwards Plateau margin and prairies beyond to the east, between about A.D. 1000 and 1300. At its core, this research module sought to provide an explanation for similarities in material culture that Shafer saw between some Late Prehistoric sites in central Texas and Caddo sites in east Texas, particularly the civic-ceremonial center at the George C. Davis site in Cherokee County.

This monograph was the culmination of many years of observation, thought, and analysis Shafer had given to the subject, starting with visits to central Texas sites in his youth in the 1950s, followed by abundant hands-on experience with materials from the region through association with the Texas Archeological Research Laboratory and his 1973 Ph.D. dissertation on the lithics from the George C. Davis site, followed by maturation of an interpretive perspective gained from research outside Texas (Mesoamerica and the U.S. Southwest). He presented an early version of this hypothesis in a paper delivered at the 2003 meetings of the Texas Archeological Society. Fortuitously, Prewitt and Associates, Inc., had undertaken data recovery excavations at a site (J. B. White, 41MM341) that was relevant both geographically and temporally to Shafer's model in 2002, and analysis of the information from that site, which was ongoing through 2006, was able to benefit from Shafer's ideas. This is what spurred TxDOT to provide funding and support (through Prewitt and Associates) to Shafer so that he could fully articulate his ideas in print

Although there was communication between Shafer and Prewitt and Associates staff about his research module and our interpretations of the J. B. White site between 2003 and 2006, the two efforts were not truly integrated. Shafer concluded that J. B. White fit the expectations of his model, but we reached a different conclusion. We presented that conclusion in the technical report on the excavations (Gadus et al. 2006:177-182) and in an abbreviated fashion in an exhibit on the Texas Beyond History website (http://www.texasbeyondhistory. net/jbwhite/index.html). I reiterate the argument here to provide an outlet for discussion of this topic beyond the gray literature generated by cultural resources management projects.

\section{The Prairie Caddo Model}

As Shafer (2006:1) notes, "The idea that the Late Prehistoric peoples who occupied the area of the Middle Brazos and its tributaries - especially the Leon and Bosque Rivers and their tributaries - might be Caddo came from my realization that there was an assemblage in the Late Prehistoric period in central Texas that did not fit the currently applied Toyah and Austin systematics... Furthermore, there appeared to be ties in 


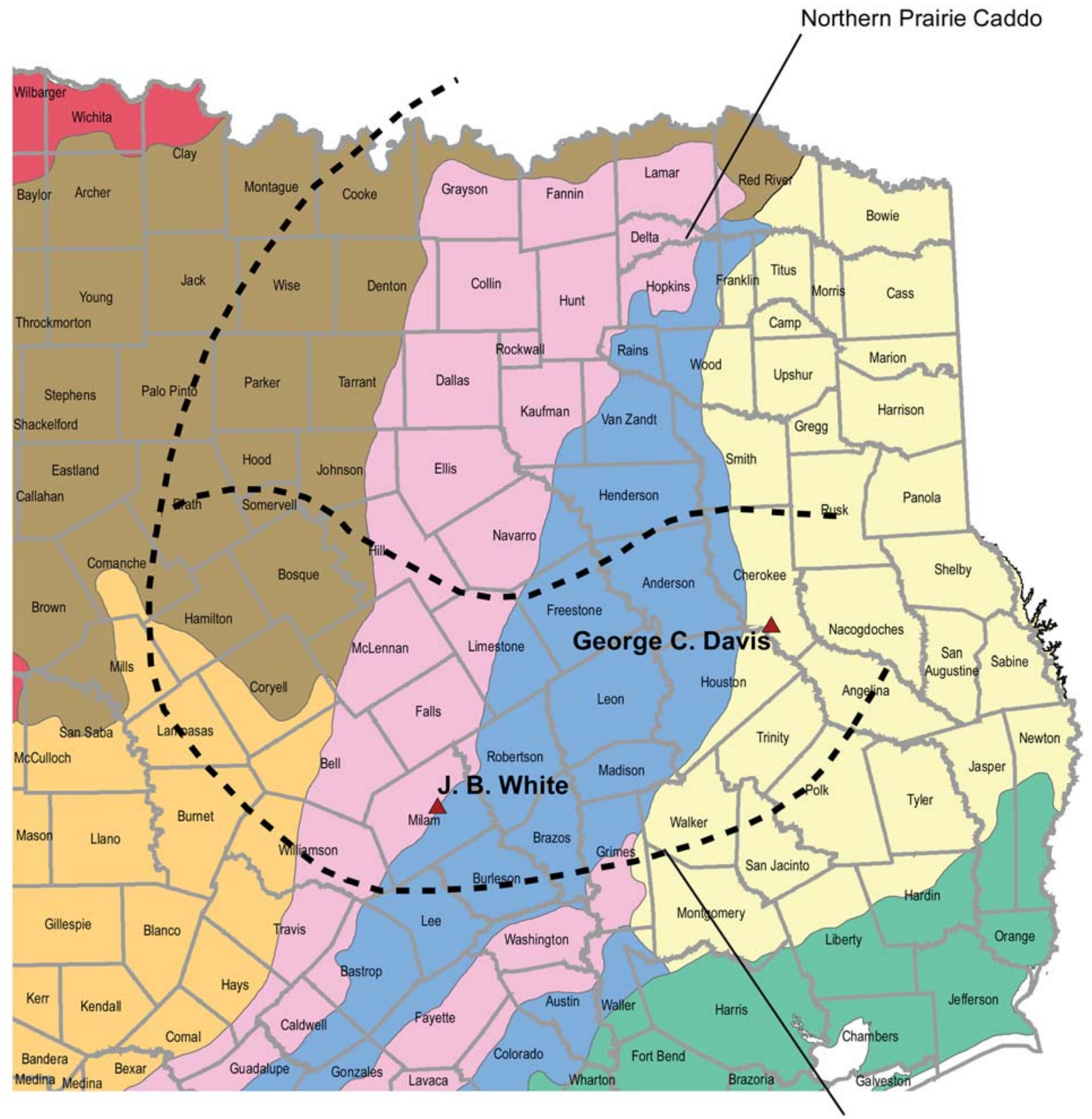

Legend

Southern Prairie Caddo
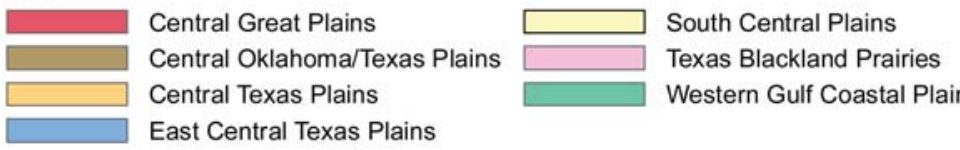

Western Gulf Coastal Plain

Figure 1. Map showing the geographic extent of the area encompassed by the Prairie Caddo model and the locations of the George C. Davis and J. B. White sites. Map adapted from Level III Ecoregions from Omernik, J. M., Ecoregions of the conterminouse United States, 2003. Available through the Texas Parks and Wildlife GIS Lab: http://www.tpwd.state.tx.us/landwater/land/maps/ gis/data_downloads/

this central Texas assemblage with the George C. Davis site, especially with regards to the ceramics, arrow point styles, and Gahagan bifaces. ${ }^{1}$ These similarities

${ }^{1}$ Dee Ann Story (1990:364) had made these observations as well. suggested to me that a possible connection between the two was perhaps more than merely the result of trade and exchange." A third impetus for this idea was the view of "the George C. Davis site as a regional ceremonial center 
that served as a magnet to attract, and perhaps to maintain some jurisdiction over, outlier villagers that sustained the ceremonial center" and the long-held perception that the immediate area of the site lacked archeological evidence of the substantial population required to maintain such a center (Shafer 2006:2, 32). Shafer (2006:32-33) knew, of course, that geophysical surveys starting in the early 2000s had found a surprisingly large number of buildings at the site, raising the possibility of a much larger resident population than was suspected up to that point, but he did not concur with this interpretation, instead believing that these were buildings used for short periods of time based on the absence of middens.

In short, the Prairie Caddo model proposes the following: (1) part of the population that supported and contributed to ceremonial activities between A.D. 1000 and 1300 at the George C. Davis site lived on the Blackland Prairie and eastern Edwards Plateau, extending Caddo territory as much as $300 \mathrm{~km}$ west of the site; (2) these western Caddo peoples were largely hunter-gatherers who may have augmented their subsistence pursuits with agriculture at some times and in some places; (3) these groups provided prairie resources, including Gahagan bifaces and Bonham-Alba arrow points made of central Texas cherts, to the elites who lived at the ceremonial center; (4) these western groups provided a "defensive buffer to the vulnerable frontier position of the Davis site"; (5) permanent Caddo occupation occurred in "portions of the central Brazos valley with intermittent and interdigitated Caddo presence in the peripheries to the west and south", leading to the latter being "contested territories" between Caddo and non-Caddo groups; (6) western Caddo peoples regularly traveled to the George C. Davis site to participate in feasting associated with ceremonies, with "such events provid[ing] stimulus and mechanisms for style display and material exchange" and "stimulat[ing] production and patterning in certain kinds of material culture [that] was centered at the George C. Davis site"; (7) the settlement pattern created by the western Caddo groups consisted mostly of small campsites where artifact assemblages might not look very Caddoan, but also larger villages with ceramic-rich assemblages; and (8) Prairie Caddo peoples obtained mostly utilitarian pottery vessels when they visited the Davis site for ceremonies and carried them back westward, where they used them, chiefly in their larger villages, for domestic purposes" (Shafer 2006:1, 3, 7, 9, 10, 26, 32-34, 40, 41).

The Prairie Caddo model was considered to apply to a great swath of the eastern part of Texas, extending from the Red River down to roughly Austin and College Station. As indicated above, however, the argument focused strongly on the south part of the region, i.e., Cherokee County where the George C. Davis site is and points westward. This was termed the "Southern Prairie Caddo" area (see Figure 1).

The analysis presented to support the model took an approach based on identification of technological styles represented in four kinds of material culture: early Caddo pottery, deer metapodial beamers, Bonham-Alba arrow points, and Gahagan knives (Figure 2). Shafer (2006:10-24) examined the distributions of these kinds of artifacts (and a fifth, bone needles, which likely were associated technologically with beamers) to demonstrate connections between east Texas Caddo sites and sites in central Texas, and he followed this with suggestions for how to test hypotheses arising from the model and an extended discussion of why the George C. Davis site in particular is relevant to the model.

\section{The J. B. White Site}

The J. B. White site (41MM341) is at the eastern edge of the Blackland Prairie in central Milam County, Texas, just southeast of the town of Cameron and about $100 \mathrm{~km}$ northeast of Austin (see Figure 1). It occupied a low rise in the modern floodplain of the Little River and contained partially stratified, multicomponent prehistoric materials encased in the upper $90 \mathrm{~cm}$ of a late Holocene alluvial soil buried beneath $40-50 \mathrm{~cm}$ of nearly sterile alluvium (Figure 3).

The excavations focused on broad exposure in three blocks, a large main one and two smaller ones to the east and south, of the remains of a series of Late Prehistoric occupations in the upper $50 \mathrm{~cm}$ of the buried soil. Archeological remains were present below this (at $50-90 \mathrm{~cm}$ in the buried soil) but were not targeted because they were so sparse. The excavations, which consisted of 4 backhoe trenches and $217 \mathrm{~m}^{2}$ of manual excavations, found 50 interpretable cultural features consisting of surface hearths, pit hearths, processing pits, mussel and snail shell lenses, burned rock concentrations, and possible postholes. The Main and East Blocks both contained diverse feature assemblages, unlike the South Block which had almost exclusively baking pits (Figure 4). Not recorded as features in the field but treated as such during data analysis because they indicate spatially restricted loci of particular activities were 10 concentrations of lithic reduction debris in the Main Block representing discrete episodes (or sets of episodes) of stone tool production (Figure 5). The collection of artifacts and other cultural materials was large, consisting of 303 shaped chipped stone tools; 494 expedient stone tools; 168 cores; 39,872 pieces of unmodified debitage; 30 stone tools modified by grinding or battering; 30 bone tools or modified bones; 4 ceramic sherds; 6,540 pieces of vertebrate faunal remains; more than $58.2 \mathrm{~kg}$ of invertebrate faunal remains; $1.6 \mathrm{~kg}$ of macrobotanical 

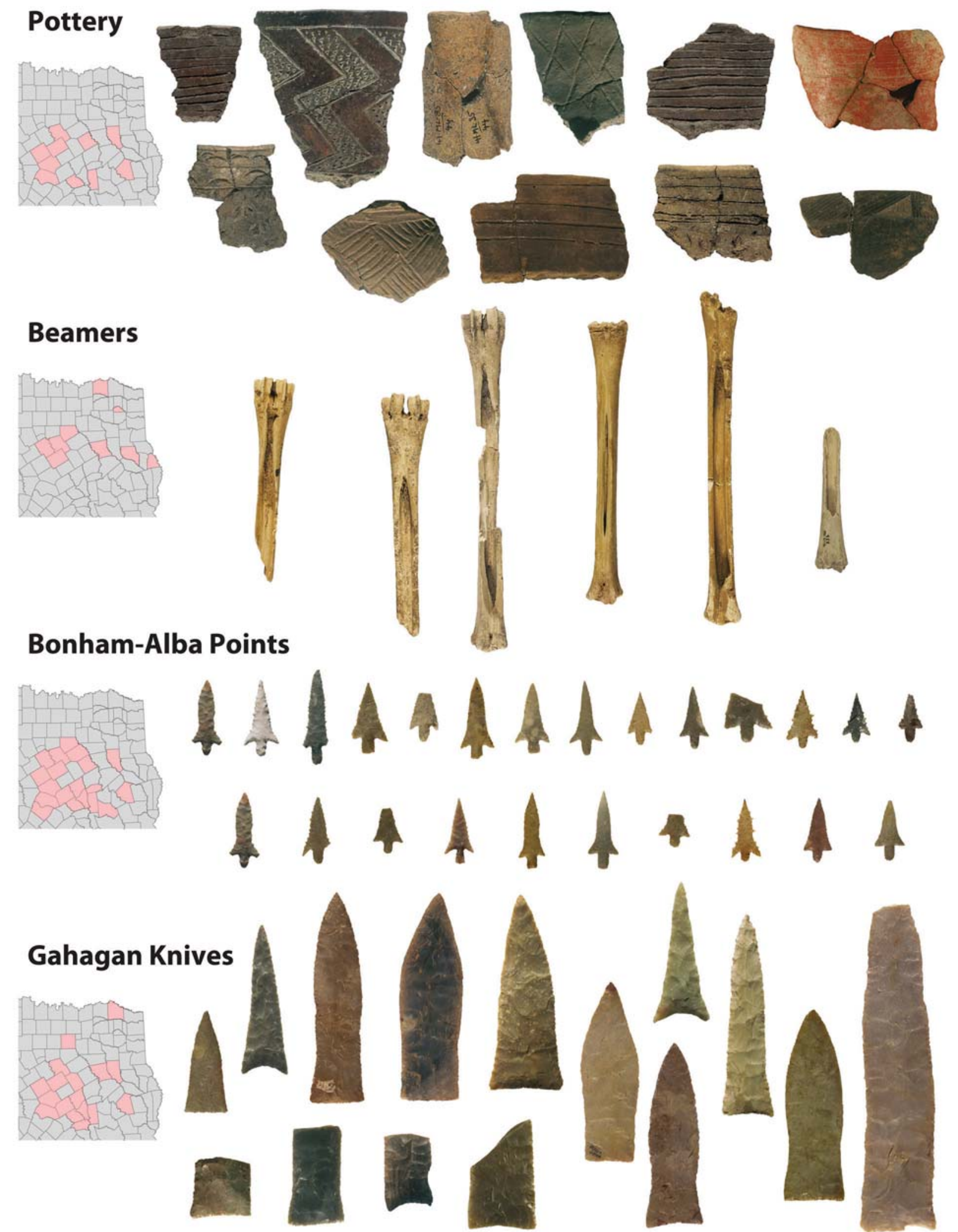

Figure 2. Examples of the four main kinds of material culture used in formulating the Prairie Caddo model and maps showing their distributions. 


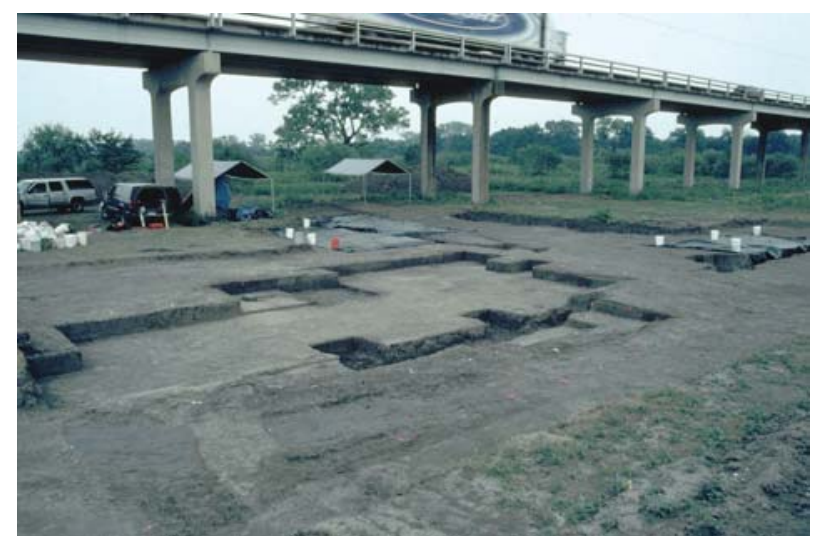

Figure 3. View to the southeast of the J. B. White site during excavation. The tall highway bridge that crosses it emphasizes the floodplain setting.

remains; $163.0 \mathrm{~kg}$ of burned and unburned rocks; and $30.0 \mathrm{~kg}$ of burned clay.

The cultural deposits in all three blocks occurred as patchy lenses of artifacts and ecofacts associated with intact features. Because the lenses were not widely separated within the alluvium and because the excavations were done in arbitrary $10-\mathrm{cm}$ levels, it was not possible to segregate them into a neat series of sequential occupations. But it was possible to separate the 40-cm-thick primary deposit into two analytical units, an earlier one (Analysis Unit 2) dating to A.D. 800/900-1100 and a later one (Analysis Unit 1) dating to A.D. 1100-1300. Below these units were sparser cultural materials relating to an occupation in the A.D. 600s and maybe 700s (Analysis Unit 3) ${ }^{2}$. The excavation data were analyzed and interpreted on two levels. One used the three analytical units noted above to look at components broadly defined - that is the ca. 200-year-long spans of time that could be identified most consistently and most reliably across the Main Block and between it and the East and South Blocks. These analysis units were useful for characterizing the occupations in terms of the ranges of features and tool types used (and hence activities) and the subsistence resources utilized and for looking at how these did or did not change through time. On a finer level, interpretation of the spatial distributions of some of the remains revealed that some remnant patterning relating to the arrangement of activities was preserved, providing insights into site structure and function.

It was observed during excavation of the Main Block and in analysis that the lithic reduction debris piles often co-occurred with materials such as burned rocks, mussel shells, and animal bones, and that surface hearths were positioned adjacent to these material concentrations. The co-occurrence of food refuse, tools, tool manufacturing debris, and hearths in semidiscrete

\footnotetext{
${ }^{2}$ The chronology of the analytical units was determined based on 36 radiocarbon dates.
}

concentrations lends itself to an explanation akin to the workshop-habitation site formation model of Stevenson (1985). This distributional pattern was clearest in Level 8, assigned to Analysis Unit 2, which contained five surface hearths: Features 8, 25, 30, 35, and 40 (Figure 6). Features 8 and 25 were $4 \mathrm{~m}$ apart in the southeastern part of the block, and Features 30, 35, and 40 were $3-4 \mathrm{~m}$ apart in the northwestern part. The two groups of hearths were 7-8 $\mathrm{m}$ from one another. Features 8,35 , and 40 were within or on the edges of concentrations of various materials, while Features 25 and 30 were not. The fact that Features 25 and 30 were off by themselves suggests they had different use histories than the other hearths or were used for different purposes.

This configuration and the distances between hearths and between the groups hints at some consistency in the placement of cooking and heating facilities that would seem unlikely if the materials in Level 8 represented many occupations over a long span of time. Rather, this layout is what would be expected if the features were created during a single occupation, or perhaps multiple occupations that were separated by short intervals, such that the remains of the last occupation were still visible.

The concentrations of materials near Features 8, 35 , and 40 were similar in some ways, but the differences between them suggest they were not fully equivalent to one another. For example, large concentrations of mussel shells pointing to processing of mussels were present only around Feature 8, where they were recorded as features. A small concentration of shells was present $2 \mathrm{~m}$ southeast of Feature 35, but it was not large or obvious enough to get a feature designation. Mussel shells were not abundant near Feature 40. Instead, Rabdotus shells were especially common there, with one large concentration south of the hearth recorded as a feature. Analysis of the shells indicated that the snails almost certainly were procured for food. Much smaller snail concentrations were $1.5 \mathrm{~m}$ southeast of Feature 8 and $3.5 \mathrm{~m}$ southeast of Feature 35. Concentrations of animal bones, also representing discarded food debris, covered extensive areas south and southeast of all three hearths. Within these were spirally fractured bones suggesting marrow extraction.

One thing that the Feature 35 area had that the others did not was overlapping concentrations of burned clay, burned rocks, and burned rock shatter ca. $2.5 \mathrm{~m}$ southeast of the hearth. Since burned rock shatter was almost nonexistent in the hearths, these burned materials probably do not represent hearth cleaning. Instead, they may represent a small heating or cooking feature that was not distinctive enough to be recognized and recorded as a feature during excavation. The Feature 35 area also had extensive, partly overlapping concentrations of burned rocks and burned clay east and south of the hearth that could represent materials removed from Feature 35 or 

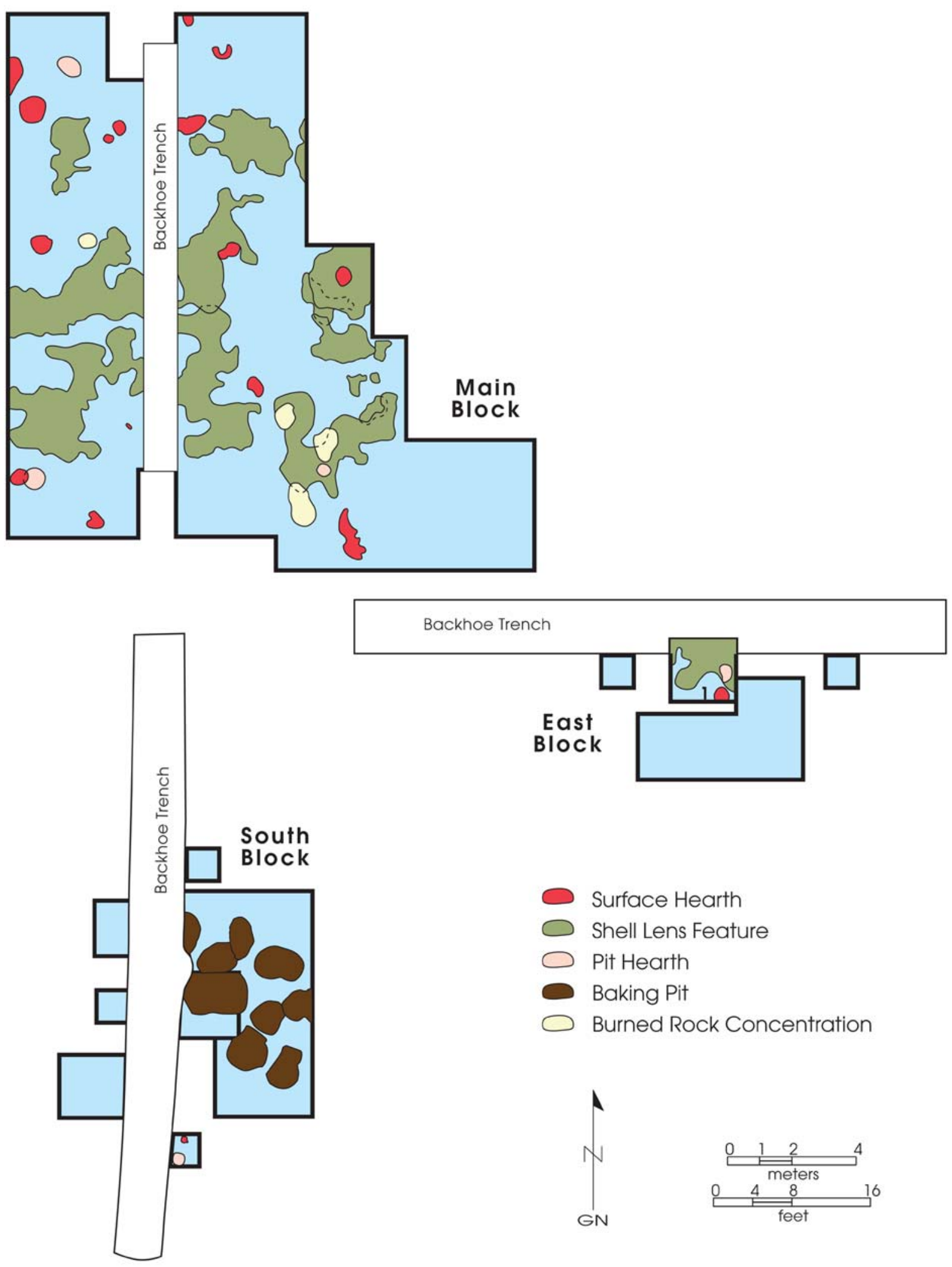

Figure 4. Plan of the excavations at the J. B. White site showing cultural features. 


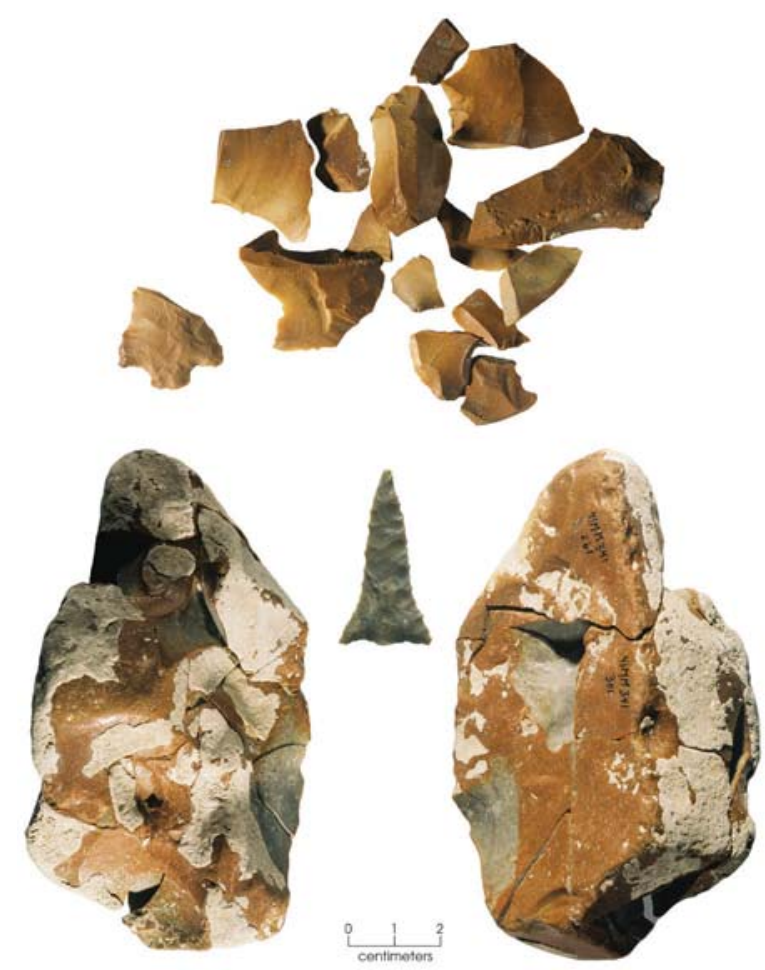

Figure 5. Two examples of materials from lithic reduction debris piles at the J. B. White site. The upper one (from Pile 5) shows an arrow point broken during manufacture (lower left) and matching debris. The lower one (from Pile 1) shows two views of an almost completely reconstructed cobble (missing only one interior flake) and a broken arrow point (middle) found nearby that likely was made from that flake.

perhaps reflect activities centered beyond the block to the west. Non-overlapping areas of concentrated burned rocks and burned clay occurred around the other two hearths and also could indicate cleaning out of cooking features.

All three hearths were near concentrations of lithic reduction debris. Pile 7 was spread out mostly on the south side of Feature 8, with its core about $2 \mathrm{~m}$ southeast of the hearth. The core of Pile 6 was ca. $1.5 \mathrm{~m}$ southsoutheast of Feature 35; this pile was part of an extensive concentration of debitage that stretched southeast of the hearth and ran west to the edge of the block and probably beyond. Pile 10 was south and east of Feature 40 . As with the other two areas, its core was ca. $2 \mathrm{~m}$ from the hearth, in this case south-southwest of it. Based on the analyzed debitage from Piles 6 and 7, both formal tool production and flake production for use as expedient tools generated the piles, and it is surmised that this is the case with Pile 10 as well.

Not reflected on Figure 6 is the fact that the overwhelming majority of the formal chipped stone, ground or battered stone, and bone tools (67 percent in Level 8) and expedient stone tools (79 percent) were within the main parts of the debris scatters (i.e., the areas where multiple classes of debris tend to be especially abundant). This indicates that most activities associated with tools occurred in close proximity to the areas marked by the hearths and surrounding debris scatters. The higher percentages for expedient tools probably is a function of the selection of flakes from the lithic reduction debris piles for immediate use followed by discard on the spot.

These distributions of food remains, tools, and debris from lithic tool production around hearths indicate that both workshop and living-related activities were performed in the same areas. The remains in Level 8 may not be from a single occupation, but the concentrations can be interpreted as representing a series of occupations with similarly structured activities that likely occurred within a restricted time frame. The configuration of these workshop-habitation areas arcing around a space ca. 4-5 $\mathrm{m}$ in diameter where artifact densities were uniformly low could even suggest that they were placed relative to a shade tree or other fixed feature, or perhaps just to leave open space between them, although this interpretation obviously would require that all the hearth areas relate to a single occupation. The central, empty area could even have contained a structure, although there is no positive indication of this, and the scarceness of all classes of cultural materials there argues otherwise. Structures almost certainly were built at the site, but the available evidence does not tell us where they were or what they looked like.

The limited excavations in the East Block indicated that the cultural deposits there were much like those in the Main Block. This was not the case for the South Block, however. The South Block was placed over a concentration of processing pit features, which were distinct from the features elsewhere on the site in terms of their larger size and greater intensity of burning. The highly fragmentary nature of the burned rocks, along with the fact that the processing pits intersected one another, suggest that this area was used repeatedly for the same purpose, apparently processing of both animal and plant foodstuffs. Based on their level of origin and the radiocarbon dates, these processing pits appeared to be associated with Analysis Unit 1. They represent a distinct kind of activity area that contrasts with those sampled by the Main Block, and the addition of these activities during the later occupations may relate to increased intensity of use during that time. Test units (not shown on Figure 4) and trenches revealed that the area between the blocks was relatively devoid of cultural materials in the levels relating to these occupations, and hence the activities associated with these processing pits were isolated from the activities that produced the workshop-habitation areas in the Main Block by about $10 \mathrm{~m}$ of empty space. 


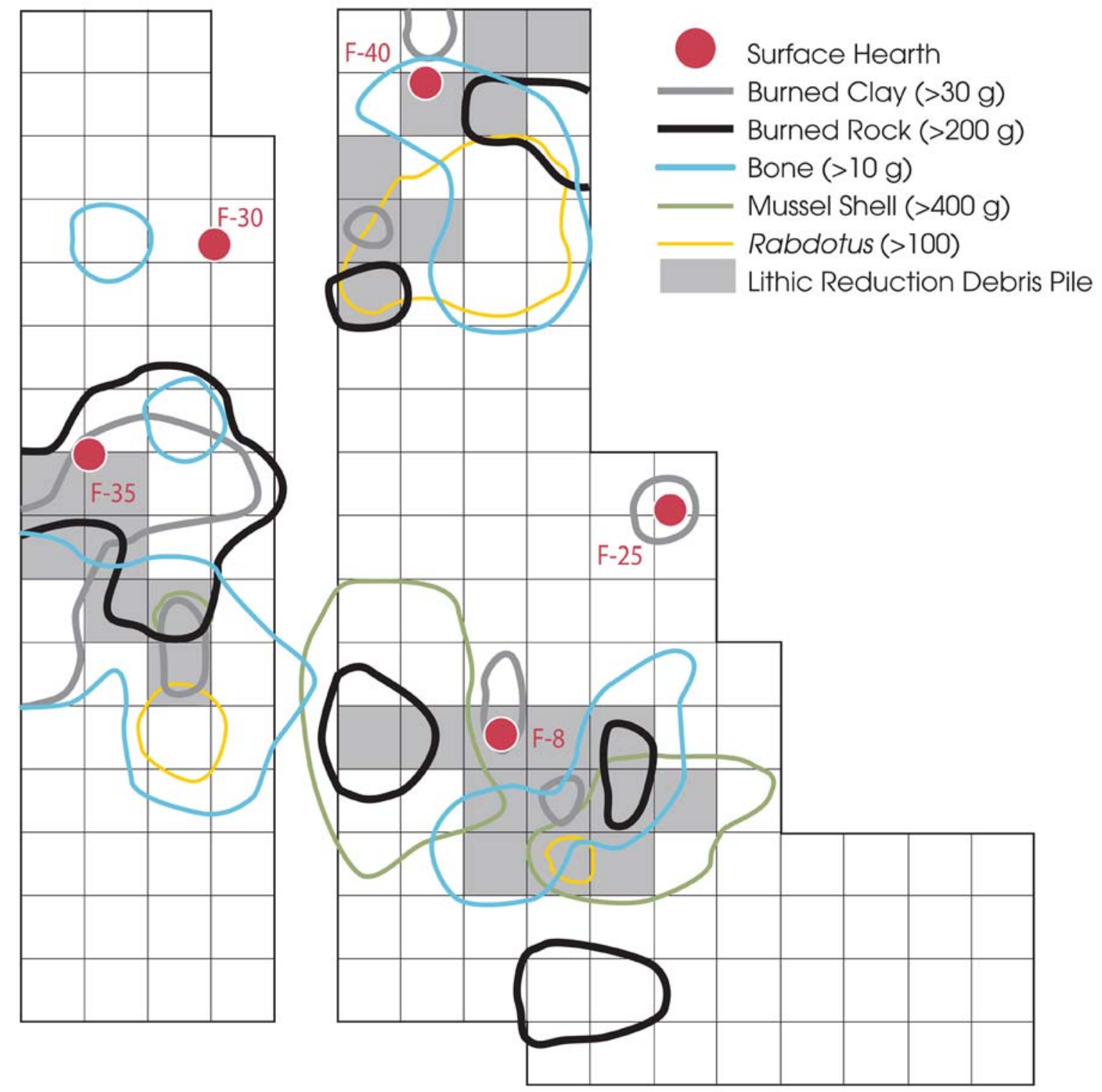

Figure 6. Plan of Level 8 in the Main Block at the J. B. White site showing hearth locations and material distributions.

Among the many kinds of artifacts recovered, four groups in particular are relevant to the Prairie Caddo model: ceramics, bone needles, arrow points, and Gahagan bifaces. Only 4 small ceramic vessel sherds were found. None can be identified with certainty as Caddo ceramics, and in fact one sandy paste specimen is surely not from a Caddo vessel. Further, their associations are unclear. They could go with the sparse cultural materials in the uppermost deposits of the site that were stripped off before the block excavations began (13 sherds found in these upper deposits during testing in 2000 by archeologists with the University of Texas at San Antonio were thought to relate to a Toyah phase occupation), or they could go with the occupations represented by Analysis Units 1 and 2. Even if the latter is true, though, it is clear that ceramic vessels played virtually no role in activities performed at the site.

The excavations did not yield any metapodial beamers, but among the 30 bone tools and worked bone fragments were 6 fragments representing 3 bone needles (Figure 7), as well as debris indicating onsite manufacture of needles. Shafer (2006:15) notes that "bone needles are an added material element for a technological system incorporating metapodial beaming tools that might 


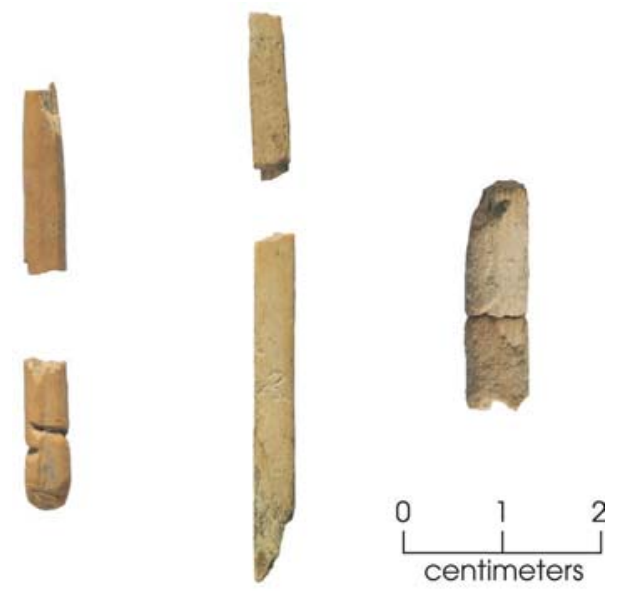

Figure 7. Bone needles from the J. B. White site.

suggest sewing tailored garments", and their presence at J. B. White is one of the pieces of evidence that could be used to identify it as a Prairie Caddo site.

More compelling, though, are the arrow points, all of which likely were manufactured at J. B. White judging from their frequent association with the lithic debris reduction piles. Eight of the typed specimens are Perdiz, and 16 are Albas (Figure 8); the other 26 are Scallorns. Most of the Perdiz would have been classed as Bonham-Alba by Shafer and thus would be consistent with his Prairie Caddo assemblage. Further, many of the Alba points have finely worked recurved blades and are indistinguishable technologically and in terms of raw materials from the numerous examples from the George C. Davis site (Shafer 1973:196-204). That arrows with Alba points were significant cultural and social markers is demonstrated by their use as burial offerings at Davis. The occurrence of Alba points in jumbled clusters and clusters of aligned points suggests they were deposited as containers of unhafted points and quivers of hafted points. Shafer (1973:194-195) illustrates 24 Alba points selected from the 150 recovered from Feature 134. The varied stem and base characteristics of all the Alba points from J. B. White are present in this illustrated group of 24. Similar diversity in form is seen in Alba points from a possible quiver of 28 recovered from Feature 161, Cluster 1, at the Davis site (Shafer 1973:199-202). Such diversity in points from a single instance in time suggests a collection of points fashioned by various knappers, and the presence of arrows from many knappers in a single quiver or container suggests trade in finished arrows or arrow points. Sites on the eastern margin of central Texas, like J. B. White, are where some of these traded items originated.

Equally telling is the collection of 31 knives and knife fragments and 24 knife preforms, all made at the site. The more-complete finished tools indicate a bifacial form consisting of a thin, elongated, triangular blade with straight, recurved, or convex edges that are even, finely pressure flaked, and occasionally serrated. Three specimens are classic Gahagan knives, with flaring near- base lateral edges and a concave base, and 4 specimens have the straight lateral edges with straight base characteristic of Friday knives (Figure 9). The conclusions given above about the cultural and social significance of Alba points at the Davis site also apply to Gahagan knives, since they occurred in the same contexts. Like Alba points, many if not all of the Gahagan knives that ended up at the Davis site must have originated on the eastern margin of central Texas.

In sum, the J. B. White looks very much like a general-purpose campsite occupied perhaps mostly during the drier summer months by complete social groups of hunter-gathers long enough each time for a range of procurement, processing, and manufacturing activities to be performed and represented in the archeological record. They took mussels and fish from the Little River and hunted a variety of game, especially deer, on the surrounding floodplain and adjacent uplands. They may have used botanical resources less, although they did consume hardwood nuts and wild onion and false garlic bulbs. One important activity performed at the site was manufacture of stone tools - mostly arrow points, knives, and expedient flake tools - using chert collected from gravel bars in the river. Many of these tools were used in the wide variety of activities that typified daily life there, but some appear to have been made because they would be needed later after people left the site. One anticipated need was for items that would facilitate interaction with their Caddo neighbors to the east.

\section{Does the Prairie Caddo Model Help Interpret the J. B. White Site?}

The evidence summarized above and the results of geochemical analyses of Caddo vessel ceramics from numerous sites in central Texas (Perttula et al. 2003:63) show unequivocally that there was substantial movement of pottery westward into central Texas and arrow points and knives eastward into the Caddo homeland during the Late Prehistoric period. The Prairie Caddo model hypothesizes that, during the interval between A.D. 1000 and 1300, this was because the residents of part of central Texas, i.e., the Brazos River valley at and 


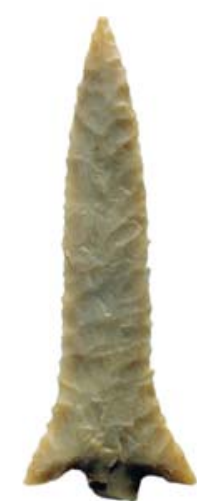

a

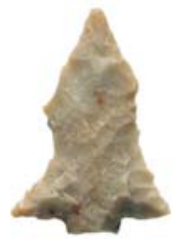

h

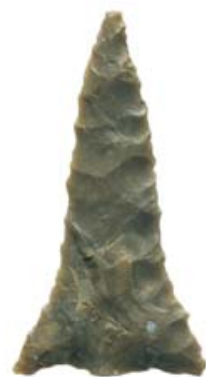

b

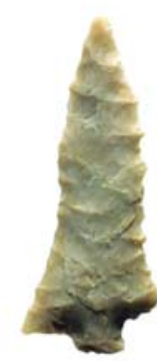

C

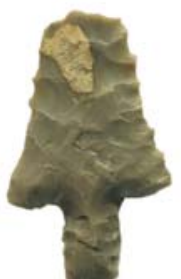

d

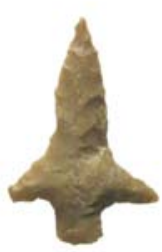

e

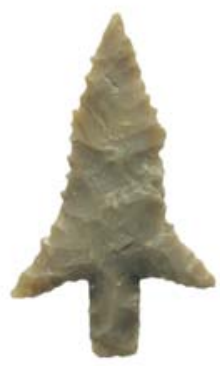

f

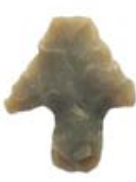

$\mathrm{m}$

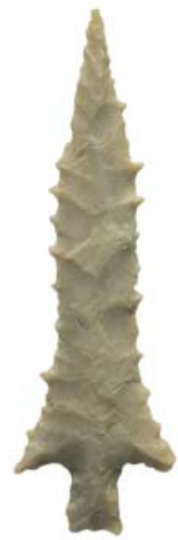

g

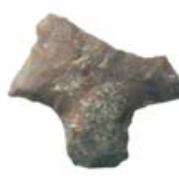

i

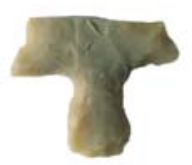

j

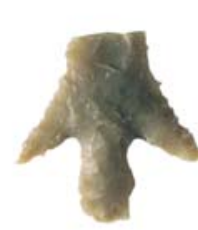

k

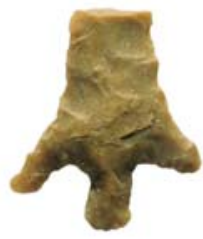

।

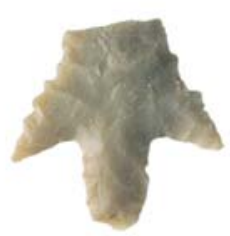

q

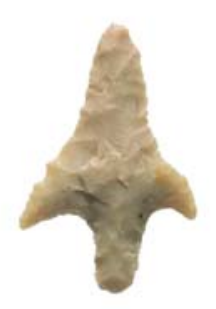

u

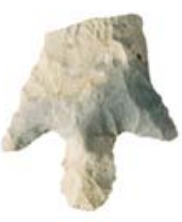

$r$

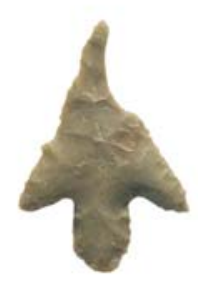

S

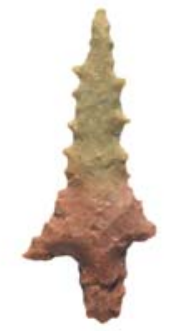

†

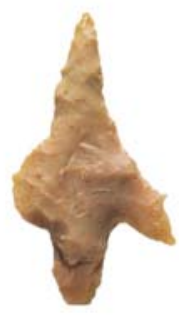

V

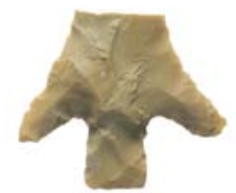

$n$

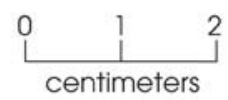

Figure 8. Alba and Perdiz points from the J. B. White site. (a-n) Alba; (o-v) Perdiz.

east of the Balcones Escarpment, were Caddo people controlled by religious and political leaders tied to the George C. Davis site on the east side of the Neches River in Cherokee County. The data from the J. B. White site do not support this interpretation, however. J. B. White did yield three of the four kinds of items that the model posits as material correlates of a Prairie Caddo social identity (Bonham-Alba arrow points, Gahagan knives, and bone needles as stand-ins for deer metapodial beamers), but it yielded almost no ceramics. This is unlikely to be the result of sampling error or site function. It is true that some unknown portion of the site outside the project 

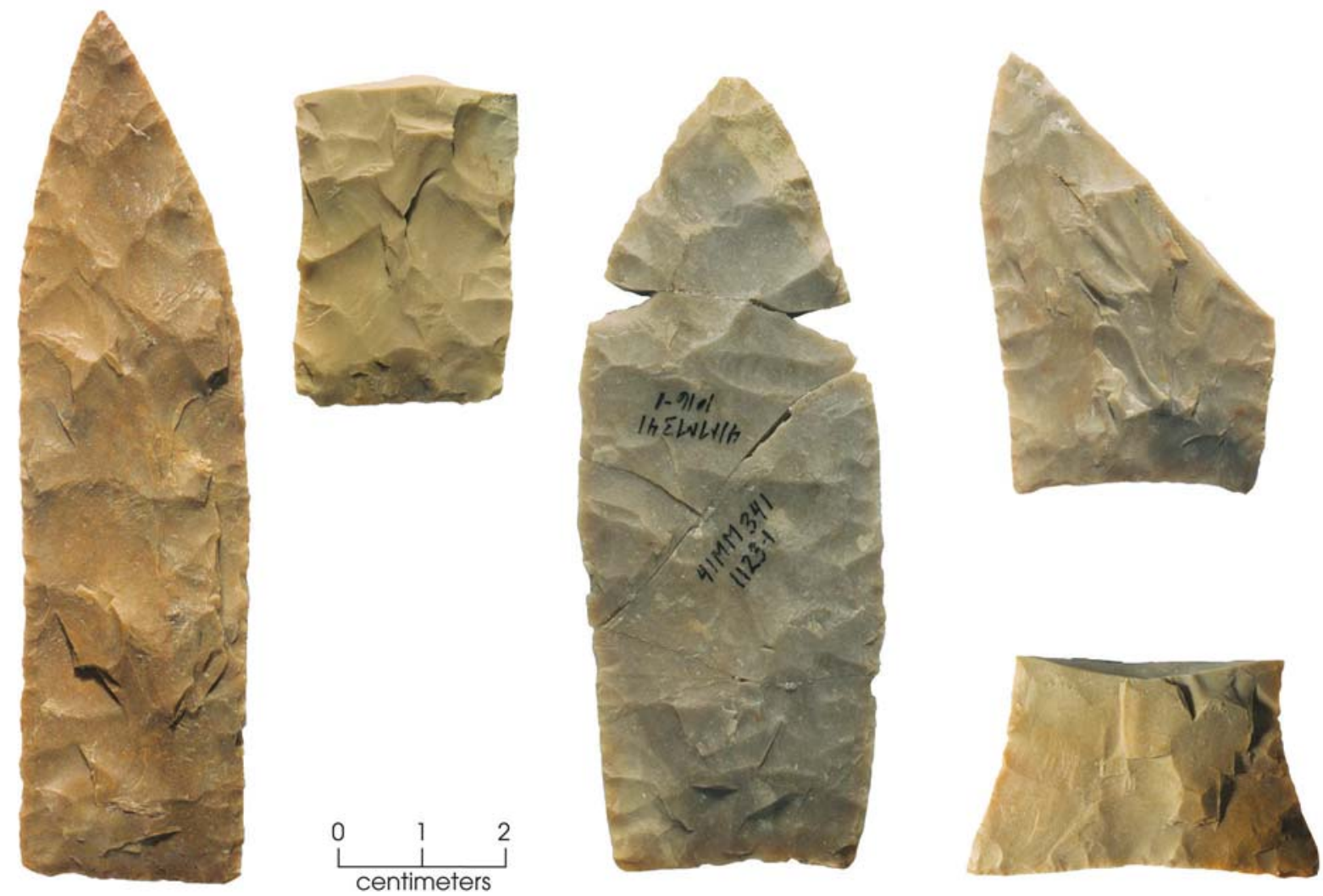

Figure 9. Gahagan and Friday knives from the J. B. White site.

area (which was restricted to the proposed highway right of way) was not examined, but to expect that ceramic sherds could have been deposited only in that area is unrealistic given the extent of the excavations $\left(217 \mathrm{~m}^{2}\right.$ plus 4 backhoe trenches) and how many times the site must have been occupied over the ca. 400 years that Analysis Units 1 and 2 represent.

The site function argument would hinge on the idea that ceramic vessels may have been used less at floodplain sites such as J. B. White than at moresubstantially used base camps situated higher on the landscape. The counter to this is that, when you consider all the evidence and not just the artifacts, J. B. White does not look at all like a special-purpose or limited- function site. It is true that it is in a setting that would not have been conducive to year-round occupation, but the features and cultural materials found indicate a wide variety of activities associated with procurement, processing, maintenance, and gearing-up tasks. The site appears to have functioned as a general-purpose campsite where Native Americans brought subsistence resources and raw lithic materials collected nearby and from more-distant locations. Mussels and lithic cobbles came from the river, which was at or near its current position no closer than $0.4 \mathrm{~km}$ from the site, and some of the hardwood nuts and other subsistence resources probably came from upland areas farther away. The Native Americans processed these resources in various ways and consumed them, and then prepared for their next move in the seasonal round. If ceramic vessels were part of the material culture of these people, why would they not have needed them to perform some of these tasks? In this case, parsimony leads to the conclusion that pottery was not part of the material culture, removing one of the linchpins of the Prairie Caddo artifact assemblage.

So, how do we interpret the obvious connections between sites like J. B. White and Caddo sites in east Texas, in particular the George C. Davis site? The keys are Alba and Bonham (or eastern-style Perdiz) arrow points and Gahagan knives. As noted, some of the tools of these forms found at J. B. White are essentially identical in terms of workmanship and raw materials to those found at the Davis site. These similarities suggest that points and knives that ended up as grave goods in burials of the Caddo elite at the Davis site were made in the vicinity of J. B. White, perhaps by people who occupied the site at one time or another or by related groups. The people who lived at J. B. White and westward to the Balcones Escarpment and probably eastward to the Brazos River (an east-west span of about $90 \mathrm{~km}$ ) had access to highquality raw materials, and they had the skills to produce finely crafted arrow points and knives. Many such 
tools were manufactured at J. B. White, and evidence of reworking and breakage patterns show that many were used and discarded there. The high frequency of manufacture breaks relative to use breaks, however, hints at the importance of gearing-up activities. Whether these activities were in response to anticipated hunting and butchering needs after seasonal abandonment of the site, or in anticipation of having goods for future interactions with people who lived in east Texas, is not known. What does seem certain, though, is that somewhere people involved in the same cultural system that resulted in J. B. White decided it was advantageous to manufacture lithic tools that ultimately would be transported to the Davis site.

The Prairie Caddo model would posit that this decision was made by frontier Caddo people who needed something of value to offer, perhaps as tribute, when they traveled across the Brazos, Trinity, and Neches Rivers for feasting and other communal activities at the Davis site. As noted above, the lack of ceramics at J. B. White and other characteristics of the site argue for a simpler explanation. Instead, based on the information from J. B. White and the Hoxie Bridge site at Granger Lake in Williamson County closer to the Balcones Escarpment (which, like J. B. White, yielded Darl dart points and Scallorn, Alba, and a few Perdiz arrow points along with Gahagan bifaces and a small number of sherds, most of which appear not to represent Caddo vessels; Bond 1978), it appears that the Little River valley and those of its tributaries were used in a consistent fashion from at least A.D. 600 to 1300. During the early part of this interval, these people used both Darl dart points and Scallorn arrow points. This was succeeded by a period where Scallorn points were the chief hunting implement. Alba arrow points were added to the repertoire, perhaps around A.D. 1100, and may have been used along with Scallorn points for a time. Perdiz points (or Shafer's Bonham points) were added toward the end of the interval, by which time the Scallorn form probably had dropped out of favor. All three arrow point forms are similar technologically in terms of their blade treatments, and it appears that this whole sequence was part of a single tradition created by a single cultural group, or maybe a small number of related groups.

Coupled with the consistency in site use over time, this looks very much like a local development among hunter-gatherers who were well adapted to the Blackland Prairie and the ecotonal areas at its east and west margins. Among the resources that these people knew how to exploit were the local chert gravels. By A.D. 1100 or a century or two earlier, they were using these gravels to make not only tools for their own use but also as goods to be used during interactions with the Caddo. This production involved particular tools following specific technological styles, but the evidence for interaction involving lithics not manufactured to such specifications (and not focused so strongly on a single east Texas site) goes much farther back in time, suggesting that this pattern of connections between the eastern margin of central Texas and the eastern part of the state was a persistent one rooted in long-held traditions. This has been documented, for example, at the Jewett Mine in Freestone and Leon Counties, where a number of caches of bifacial and unifacial tool blanks of central Texas materials have been found, and where large quantities of debitage reflecting the staged reduction of central Texas cherts (including some identical to those found at J. B. White) have been identified in sites of various ages, including some dating to Late Archaic and even earlier times (Fields 1995:325). The reasons for this interaction may have changed over time, but the pattern persisted nonetheless.

Contrary to what the Prairie Caddo model proposes, I think that the people who lived along the Little River in early to middle Late Prehistoric times were not ethnically Caddo peoples who provided support for the ceremonial center at the Davis site. Rather, I think they were a local group well adapted to their particular environs who interacted regularly with the east Texas Caddo, probably in simple face-to-face or maybe downthe-line trade relationships with limited dependencies and great group autonomy. The Prairie Caddo module implies the kinds of interaction that would create dependencies and reduce autonomy, with the social elite some 200 $\mathrm{km}$ away from J. B. White exercising control over resources and possibly the organization of production associated with those resources. I see no evidence of this at J. B. White, although I acknowledge that the paucity of local comparative data makes it hard to tell for the region at large.

Michael Nassaney (1996:188-228) has explored similar questions in relation to stone tool production associated with Toltec Mounds and the Plum Bayou culture (ca. A.D. 700-950) of central Arkansas. His investigations suggest that maintaining free access to particular resources and resisting specialization within the production process are means for minimizing dependencies. It can be argued that both of these pertain to J. B. White and the surrounding area. Certainly, the sources of the lithic raw materials from which tools were made were widespread, occurring from the Balcones Escarpment east probably all the way to the Brazos River. Their locations within this broad area were generally predictable, but they changed as gravel bars moved and new stream channels were cut. These characteristics suggest that groups local to this part of the Blackland Prairie would have had constantly shifting knowledge about where lithic raw materials could have been procured, ensuring that they had access to them while discouraging 
any attempts by others to control access. Evidence from J. B. White also indicates that the chipped stone tool production process was not specialized by segmentation (i.e., one specialist manufacturing preforms and another finishing the tools). The people who occupied J. B. White made Alba points and Gahagan knives (i.e., the tools that were in demand by east Texas elites), but these tools were finished and often used onsite. Manufacture and use of finished tools near the local lithic source suggests that the tools that were carried away from the site were likely finished as well and could have been used for hunting at a future time or as an asset for trade.

What did the groups occupying J. B. White get in return for their well-made arrows and knives? This question is difficult to answer given that much of what could have been received, such as bear fat or salt, is perishable. One benefit of trade for the occupants of J. B. White, though, could have been the establishment and maintenance of cooperative alliances, which could have helped regulate competition among groups. Alliances often have been seen to coincide with evidence of violent death (Sassaman 1995:187). Scallorn points found in the backs of several of the people buried in the Austin phase cemetery at the Loeve-Fox site about $45 \mathrm{~km}$ westsouthwest of J. B. White could indicate such intergroup conflict (Prewitt 1982:36, 42-43). Alliances aimed, in part, at modulating conflict in the middle Brazos drainage could, in fact, be reflected in the Alba arrow points in the elite burials at the Davis site. The arrows in these contexts appear to be from many different makers, and this, along with the fact that they were bundled together in bags and quivers when they were included as grave offerings, may identify these elite individuals as the architects of alliances that extended far west of the Davis site.

Such alliances could have allowed the Caddo free rein for trips west of their homeland to hunt bison, as well as to procure the coveted arrow tips and knife blades, and congregate with other people for trade at certain locales near the Balcones Escarpment. Early historic accounts frequently mention Hasinai Caddo peoples in the region, sometimes in large encampments representing multiple ethnic groups (see Collins and Ricklis [1994:16-26]). This can be attributed in part to group displacement and the need for mutual defense as new, more-bellicose groups moved in, but Collins and Ricklis (1994:25) point out that there likely was a long tradition of group congregation in the region. Surely, this would have presented opportunities for trade, and such well-known "Prairie Caddo" sites as Chupik, which produced rare items like marine shell beads and a pendant in addition to numerous ceramics (Perttula et al. 2003:13), and Asa Warner, with its large collection of Caddo sherds, might have been places where such trade congregations occurred.
In sum, there certainly was substantial movement of pottery westward into central Texas and arrow points and knives eastward into the Caddo homeland during the Late Prehistoric period. The evidence from the J. B. White site indicates that pottery was not part of the material culture of the people who lived along the Little River on the Blackland Prairie, but Alba and Bonham points and Gahagan knives were. These people were not ethnically Caddo peoples who provided support in the form of tribute or labor for the ceremonial center at the George C. Davis site. Rather, they were local huntergatherers who were well adapted to the Blackland Prairie and the ecotonal areas at its east and west margins. One of the things they were adept at was production of particular tools following specific technological styles. Tools of these particular forms were prized by the elites who lived and ruled at the Davis site, who likely obtained them through trade during hunting/trading trips west of their homeland. These trips also may have been intended to establish and maintain cooperative alliances between the Caddo and their western neighbors. Such alliances could have helped regulate competition among groups and cement Caddo influence in the region and access to it.

\section{Acknowledgments}

The figures in this article were created by Sandy Hannum. They are modified versions of figures that appeared in the technical report on the excavations (Gadus et al. 2006), the Texas Beyond History exhibit on the site (http://www.texasbeyondhistory.net/jbwhite/index. html), and People of the Prairie: A Possible Connection to the Davis Site Caddo (Shafer 2006). Permission for their use was obtained from the Texas Department of Transportation, Texas Beyond History, and Harry J. Shafer. The conclusions presented here, while fully the author's responsibility, benefited greatly from discussions with Eloise Gadus (who directed the excavations and performed much of the data analysis), Karl Kibler, and Doug Boyd.

\section{References Cited}

Bond, Clell L.

1978 Three Archeological Sites at Hoxie Bridge, Williamson County, Texas. Report No. 43. Texas A\&M Research Foundation, College Station. 
Collins, Michael B., and Robert A. Ricklis

1994 Cultural Background. In Archaic and Late Prehistoric Human Ecology in the Middle Onion Creek Valley, Hays County, Texas, by Robert A. Ricklis and Michael B. Collins. Studies in Archeology 19. Texas Archeological Research Laboratory, The University of Texas at Austin.

Fields, Ross C.

1995 The Archeology of the Post Oak Savannah of East Central Texas. Bulletin of the Texas Archeological Society 66:301-330.

Gadus, Eloise F., Ross C. Fields, and Karl W. Kibler 2006 Data Recovery Excavations at the J. B. White Site (41MM341), Milam County, Texas. Reports of Investigations No. 145. Prewitt and Associates, Inc., Austin.

Nassaney, Michael S.

1996 The Role of Chipped Stone in the Political Economy of Social Ranking. In Stone Tools, Theoretical Insights into Human Prehistory, edited by George H. Odell, pp. 181-228. Plenum Press, New York.

Perttula, Timothy K., Sergio A. Iruegas, and Hector Neff 2003 Caddoan Pottery in Central Texas: Geochemical Analyses of Ceramics from Fort Hood and Vicinity. Archeological Resource Management Series, Research Report No. 51. United States Army, Fort Hood.

Prewitt, Elton R.

1982 Archeological Investigations at the Loeve-Fox Site, Williamson County, Texas. Reprints in Archeology No. 1. Prewitt and Associates, Inc., Austin.
Sassaman, Kenneth E.

1995 The Cultural Diversity of Interactions Among Mid-Holocene Societies of the American Southeast. In Native American Interactions, Multiscalar Analyses and Interpretations in the Eastern Woodlands, edited by Michael S. Nassaney and Kenneth E. Sassaman, pp. 174-204. The University of Tennessee Press, Knoxville.

Shafer, Harry J.

1973 Lithic Technology at the George C. Davis Site Cherokee County, Texas. Ph.D. dissertation, Department of Anthropology, The University of Texas at Austin.

2006 People of the Prairie: A Possible Connection to the Davis Site Caddo. Research module prepared for the Environmental Affairs Division, Texas Department of Transportation, Austin.

Stevenson, Marc G.

1985 The Formation of Artifact Assemblages at Workshop/Habitation Sites: Models from Peace Point in Northern Alberta. American Antiquity 50(1):63-81.

Story, Dee Ann

1990 Cultural History of the Native Americans. In The Archeology and Bioarcheology of the Gulf Coastal Plain: Volume 1, by Dee Ann Story, Janice A. Guy, Barbara Burnett, Martha Doty Freeman, Jerome C. Rose, D. Gentry Steele, Ben W. Olive, and Karl J. Reinhard, pp. 163-365. Research Series No. 38. Arkansas Archeological Survey, Fayetteville. 